\title{
Penelitian
}

\section{Profil Tekanan Darah Sistolik dan Saturasi Oksigen Domba Garut Betina pada Suhu Lingkungan Tropis}

\author{
(Systolic Blood Pressure and Oxygen Saturation Profile of Garut Sheep \\ in Tropical Ambient Temperature) \\ Dian Vidiastuti*, R Harry Soehartono², Mokhamad Fakhrul Ulum², Deni Noviana² \\ 'Bagian Klinik Veteriner, Program Kedokteran Hewan, Universitas Brawijaya, Malang \\ ${ }^{2}$ Departemen Klinik, Reproduksi dan Patologi, Fakultas Kedokteran Hewan, Institut Pertanian Bogor \\ *Penulis untuk korespondensi: dianvidiastuti@gmail.com \\ Diterima 2 Juni 2014, Disetujui 25 Juni 2014
}

\begin{abstract}
ABSTRAK
Pengukuran tekanan darah sistolik (TDS) dan saturasi oksigen $\left(\mathrm{SpO}_{2}\right)$ merupakan salah satu cara pemantauan fungsi kardiovaskular untuk mengetahui resiko gangguan jantung. Tujuan penelitian ini adalah untuk mengamati dinamika TDS dan $\mathrm{SpO}_{2}$ domba garut pada pagi dan siang hari dengan variasi suhu kandang. Penelitian ini menggunakan 4 ekor domba garut betina sehat, umur produktif dan tidak bunting. Suhu kandang dicatat sebelum memulai pengukuran TDS dan $\mathrm{SpO}_{2}$. Pengukuran TDS dan $\mathrm{SpO}_{2}$ menggunakan metode non-invasif ultrasonic Doppler flow detector dengan meletakkan flat probe pada medial distal carpus dan pediatric fingertip pulse oximetry yang dijepitkan ke telinga domba. Pengambilan data dilakukan pagi dan siang hari dengan 5 kali ulangan selama 20 menit pada menit ke 0, 5, 10, 15 dan 20. Hasil penelitian ini menunjukkan pengamatan suhu kandang pagi berkisar $28-29^{\circ} \mathrm{C}$ dengan rataan nilai TDS $111,20 \pm 3,95 \mathrm{mmHg}$ dan $\mathrm{SpO}_{2}$ sebesar $96,5 \pm 0,18 \%$. Pada siang hari suhu kandang berkisar $32-35^{\circ} \mathrm{C}$ dengan rataan nilai TDS 105,25 $\pm 2,24 \mathrm{mmHg}$ dan $\mathrm{SpO}_{2} 96,9 \pm 0,22 \%$. Rataan nilai TDS dan $\mathrm{SpO}_{2}$ menunjukkan tidak terdapat perbedaan yang nyata $(p>0,05)$ antar waktu pengamatan. Berdasarkan hasil penelitian ini, variasi suhu kandang tidak mempengaruhi TDS dan $\mathrm{SpO}_{2}$ domba garut tetapi secara umum domba ini memiliki tingkat adaptasi kardiovaskular yang baik terhadap kondisi suhu lingkungan tropis.
\end{abstract}

Kata kunci: tekanan darah sistolik, saturasi oksigen, domba garut, suhu kandang

\begin{abstract}
Measurement of systolic blood pressure (SBP) and oxygen saturation $\left(\mathrm{SpO}_{2}\right)$ are non invasive method for monitoring the cardiovascular function to gain information of the risk of heart problems due to changes in ambient temperature. The aim of this is study was to observe the dynamics of SBP and $\mathrm{SpO}_{2}$ on females garut sheep with the environment temperature variation. Four adult healthy females garut sheep, productive age and not pregnant were used in this study. Enclosure temperature recorded before starting measurements. Systolic blood pressure and $\mathrm{SpO}_{2}$ measurements using noninvasive methods of ultrasonic Doppler flow detector by placing the flat probe on the medial distal carpus and pediatric fingertip pulse oximetry were clipped onto the ears of sheep. Data were collected in the morning and afternoon with 5 replications for 20 minutes ( $\min$ to 0, 5, 10, 15 and 20). The results showed that environment temperature range $28-29^{\circ} \mathrm{C}$ with an average value of SBP was $111.20 \pm 3.95$ $\mathrm{mmHg}$ and $\mathrm{SpO}_{2}$ was $96.5 \pm 0.18 \%$. During the day, the temperature reaches $32-35^{\circ} \mathrm{C}$ with an average value of SBP was $105.25 \pm 2.24 \mathrm{mmHg}$ and $\mathrm{SpO}_{2}$ was $96.9 \pm 0.22 \%$. The mean value of SBP and $\mathrm{SpO}_{2}$ showed no significant differences ( $p>0.05$ ). The results indicated that enclosure temperature no affect TDS and $\mathrm{SpO}_{2}$ females garut sheep but in general this has a good level of cardiovascular adaptation to tropical ambient temperature conditions.
\end{abstract}

Keywords: systolic blood pressure, oxygen saturation, garut sheep, enclosure temperature 


\section{PENDAHULUAN}

Domba garut merupakan salah satu domba asli Indonesia yang memiliki potensi untuk dikembangkan menjadi ternak unggulan khususnya di wilayah Jawa Barat (Tawaf et al., 2011). Suhu tropis yang panas menjadi kendala peternakan di Indonesia terhadap timbulnya stres pada ternak. Stres panas dan dingin berdampak langsung pada mekanisme kontrol dasar stroke volume seperti preload, afterload, fungsi sistolik dan diastolik jantung (Wilson \& Crandall, 2011). Paparan lingkungan dengan suhu panas dapat menimbulkan serangkaian respon fisiologis yang sangat penting dalam proses termoregulasi (Cui et al., 2005). Beberapa studi yang dilakukan pada manusia telah dilaporkan adanya hubungan antara fluktuasi tekanan darah dengan musim atau suhu lingkungan (Isezuo, 2003; Morabito et al., 2006; Murakami et al., 2011).

Tekanan darah sistolik (TDS) didefinisikan sebagai tekanan puncak dalam arteri ketika ventrikel berkontraksi dengan nilai tertinggi yang muncul pada saat pengukuran tekanan darah (Jin, 2014). Kontrol terhadap tekanan darah membantu mengurangi resiko timbulnya hipertensi dan gangguan jantung (Chen et al., 2013). Selain itu, pengukuran saturasi oksigen $\left(\mathrm{SpO}_{2}\right)$ juga berfungsi menilai status oksigenasi individu. Nilai berupa persentase saturasi oksigen darah arteri dapat menunjukkan tingkat perfusi oksigen dalamjaringan (Kyriacou et al., 2007). Pemeliharaan tekanan darah dan perfusi saling berkompetisi untuk menjaga pertukaran panas dan kecukupan oksigen jaringan (Cui et al., 2005).

Studi yang berhubungan dengan status kardiovaskular pada domba garut di Indonesia saat ini masih terbatas. Informasi mengenai TDS dan $\mathrm{SpO}_{2}$ pada domba garut bermanfaat sebagai teknik deteksi dini terhadap adanya gangguan fungsi kardiovaskular yang diakibatkan oleh stres suhu lingkungan. Gangguan berupa stress suhu lingkungan dapat berdampak negatif terhadap usaha pengembangan peternakan domba garut secara umum. Berdasarkan latar belakang tersebut maka dilakukan penelitian ini yang bertujuan untuk mengetahui profil TDS dan $\mathrm{SpO}_{2}$ dengan beberapa variasi suhu lingkungan tropis.

\section{BAHAN DAN METODE}

\section{Hewan Coba}

Penelitian ini menggunakan 4 ekor domba garut betina sehat yang telah diseleksi melalui pemeriksaan fisik dengan berat badan 27-33 kg, tidak bun- ting dan umur produktif. Pakan rumput diberikan 3 kali sehari, pakan tambahan diberikan pagi hari dan air minum ad libitum. Selama aklimatisasi, domba diberikan anthelmintik oxfendazole $5 \mathrm{mg} / \mathrm{kg}$ per oral (Feno-o bolus ${ }^{\circledR}$, Issu Medika Veterindo, Indonesia) dosis tunggal selama satu hari dan injeksi antibiotik oksitetrasiklin 6-11 mg/kg intramuskular (Vetoxy LA®, Sanbe Farma, Indonesia) satu kali dalam sehari.

Pengukuran Suhu Kandang, Tekanan Darah Sistolik (TDS) dan $\mathrm{SpO}_{2}$

Suhu kandang diukur pada pagi dan siang hari sehingga diperoleh kisaran suhu lingkungan. Nilai TDS dan $\mathrm{SpO}_{2}$ diukur pada menit ke 0, 5, 10, 15 dan 20. Pengukuran tekanan darah metode non-invasif menggunakan ultrasonic Doppler flow detector (Model 811-B®, Parks Medical Electronics, USA) dengan meletakkan flat probe pada medial distal carpus yang telah diolesi gel. Manset yang terhubung dengan sphygmomanometer (Ri-san ${ }^{\circledR}$, Riester, Jerman) dikembangkan terlebih dahulu hingga melebihi nilai tekanan sistolik, setelah bunyi pulsus arteri tidak terdengar, manset dikempiskan. Suara pulsus arteri yang terdengar pertama kali dicatat sebagai nilai tekanan darah sistolik (Creedon, 2012). Pengukuran $\mathrm{SpO}_{2}$ menggunakan pediatric fingertip pulse oximetry (CMS50QA ${ }^{\circledR}$, Contec, Cina) dengan menjepitkan alat, tepat di bagian sensornya pada pinna auricula domba yang telah dibersihkan dari rambut dan kotoran yang menempel. Suhu kandang dicatat sebelum memulai pengukuran TDS dan $\mathrm{SpO}_{2}$.

\section{Analisa Data}

Data yang diperoleh dinyatakan dalam rataan dan simpangan baku. Analisa data menggunakan analisis ragam (oneway-ANOVA) yang diolah dengan program Minitab $16^{\circledR}$ Statistycal software pada selang kepercayaan $95 \%$.

\section{HASIL}

Hasil pengamatan suhu lingkungan kandang pada pagi hari berkisar antara $27-29^{\circ} \mathrm{C}$ sedangkan siang hari berkisar $32-35^{\circ} \mathrm{C}$. Gambar $1 \mathrm{~A}$ menunjukkan nilai TDS pagi hari secara umum cenderung lebih tinggi dibandingkan siang hari. Penurunan TDS pagi terjadi pada menit ke 5 sampai ke 20. Nilai TDS yang tinggi tampak pada menit ke 15 pengamatan pagi hari. Kurva TDS siang hari memiliki kecenderungan menurun mulai awal pengamatan sampai akhir menit ke 20. Gambar 1B menunjukkan persentase $\mathrm{SpO}_{2}$ pagi terlihat sedikit lebih rendah dibandingkan si-

http://www.journal.ipb.ac.id/indeks.php/actavetindones 
ang hari. Kurva $\mathrm{SpO}_{2}$ pagi dan siang hari memiliki dinamika yang sama yaitu penurunan terlihat pada menit ke 5 , stabil pada menit ke 10 sampai 15 selanjutnya kembali menurun setelah 20 menit.
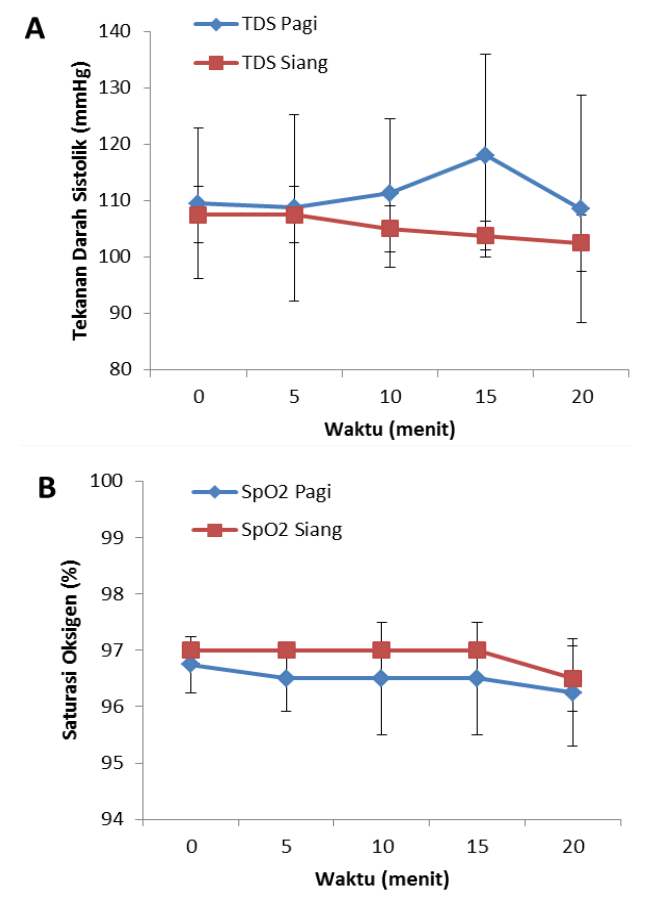

Gambar 1 A. Profil tekanan darah sistolik; B. Persentase saturasi oksigen domba garut betina dengan variasi suhu pagi $\left(27-29{ }^{\circ} \mathrm{C}\right)$ dan siang hari $\left(32-35^{\circ} \mathrm{C}\right)$ selama 20 menit

Tabel 1 menunjukkan hasil pengukuran TDS dan $\mathrm{SpO}_{2}$ dalam bentuk rataan dan simpangan baku secara statistik tidak terdapat perbedaan nyata ( $p>0.05$ ) yang terlihat pada masing-masing waktu pengukuran. Kondisi ini menunjukkan bahwa variasi suhu kandang tidak mempengaruhi nilai TDS dan $\mathrm{SpO}_{2}$ domba garut. Pada pagi hari dengan suhu kandang relatif rendah, rataan nilai TDS cenderung meningkat sebagai akibat rendahnya nilai $\mathrm{SpO}_{2}$. Pada siang hari ketika suhu kandang lebih tinggi, nilai TDS mengalami penurunan sebagai akibat peningkatan $\mathrm{SpO}_{2}$.

Tabel 1 Rataan nilai tekanan darah sistolik dan saturasi oksigen domba garut betina pada variasi suhu lingkungan tropis pagi dan siang hari selama 20 menit.

\begin{tabular}{|c|c|c|c|}
\hline \multirow[b]{2}{*}{ Waktu } & \multirow[b]{2}{*}{$\begin{array}{l}\text { Suhu } \\
\left({ }^{\circ} \mathrm{C}\right)\end{array}$} & \multicolumn{2}{|c|}{ Rataan } \\
\hline & & $\begin{array}{c}\text { Tekanan Darah } \\
\text { Sistolik (mmHg) }\end{array}$ & $\begin{array}{c}\text { Saturasi } \\
\text { Oksigen (\%) }\end{array}$ \\
\hline Pagi & $27-29$ & $111.20 \pm 3.95$ & $96.50 \pm 0.18$ \\
\hline Siang & $32-35$ & $105.25 \pm 2.24$ & $96.90 \pm 0.22$ \\
\hline
\end{tabular}

\section{PEMBAHASAN}

Rataan nilai TDS dan $\mathrm{SpO}_{2}$ domba garut berada pada kisaran yang sama dengan penelitian sebelumnya yang menyatakan TDS domba sehat berkisar 85-118 mmHg dan $\mathrm{SpO}_{2}$ sebesar 97-99\% (Adams \& McKinely, 1999; Schutz, 2011). Pada pagi hari, TDS domba garut cenderung tinggi dengan $\mathrm{SpO}_{2}$ lebih rendah. Hal ini berkaitan dengan perubahan resistensi vaskular domba yang mengalami vasokonstriksi ketika suhu lingkungan rendah sehingga terjadi peningkatan TDS. Vasokontriksi vaskular berfungsi untuk mempertahankan perfusi dan kecukupan oksigen jaringan (Crandall et al., 2008). Vasokonstriksi dan dilatasi akut, perubahan jumlah darah serta vaskularisasi jaringan berperan dalam mekanisme lokal yang mengontrol aliran darah (Chopra et al., 2011). Studi yang dilakukan oleh Kishimoto et al. (2007) melaporkan bahwa manusia dengan $\mathrm{SpO}_{2}$ rendah saat malam hari mampu mempengaruhi peningkatan tekanan darah pagi hari secara signifikan.

Tingkat perfusi jaringan yang baik pada penelitian ini ditandai dengan tingginya hasil pengukuran $\mathrm{SpO}_{2}$. Pada individu sehat, banyaknya afinitas hemoglobin dengan oksigen yang terbawa aliran darah ditunjukkan oleh persentase $\mathrm{SpO}_{2}$ yang dipertahankan nilainya lebih dari $90 \%$ (Adams \& McKinely, 1999). Schutz (2001) menyatakan bahwa afinitas hemoglobin dan oksigen mempengaruhi pelepasan oksigen ke jaringan. Oksigen yang diedarkan ke seluruh jaringan tubuh berperan dalam mempertahankan metabolisme sel agar berlangsung normal (Mc Lellan \& Walsh, 2004). Perfusi jaringan yang baik akan berdampak pada kecepatan pengisian kapiler dan sebaliknya perfusi yang buruk akan berdampak pada lambatnya pengisian kapiler (Worthley, 2000). Lebih lanjut, pengiriman oksigen perifer ditentukan oleh aliran darah dan kadar oksigen dalam arteri. Aliran darah dipengaruhi dua faktor yaitu tekanan darah dan resistensi vaskular (Kissack \& Weindling, 2009). Adanya peningkatan resistensi vaskular perifer akan berdampak pada peningkatan tekanan darah (Levy et al., 2008). Jika jumlah aliran darah sesuai dengan kebutuhan metabolik jaringan maka akan menghasilkan nilai tekanan darah yang stabil (Chopra et al., 2011).

\section{SIMPULAN}

Variasi suhu kandang yang berkisar antara 28-29 ${ }^{\circ} \mathrm{C}$ dan $32-35^{\circ} \mathrm{C}$ tidak memiliki pengaruh yang nyata terhadap dinamika TDS dan SpO2 domba garut. Secara umum domba ini memiliki tingkat adaptasi 
kardiovaskular yang baik terhadap perubahan kondisi suhu lingkungan tropis.

\section{UCAPAN TERIMA KASIH}

Ucapan terima kasih penulis sampaikan kepada Unit Rehabilitasi dan Reproduksi, Departemen Klinik, Reproduksi, dan Patologi, Fakultas Kedokteran Hewan, Institut Pertanian Bogor atas kesempatan yang diberikan untuk melakukan penelitian di bagian Unit Rawat Ruminansia Kecil.

"Penulis menyatakan tidak ada konflik kepentingan dengan pihak-pihak yang terkait dalam penelitian ini"

\section{DAFTAR PUSTAKA}

Adams D, McKinley M. 2009. The sheep. http:// www.adelaide.edu.au. Download: April 30, 2014.

Chen Q, Wang J, Tian J, Tang X, Yu C, Marshall RJ, Chen D, Cao W, Zhan S, Jun L, Lee L, Hu Y. 2013. Association between Ambient Temperature and Blood Pressure and Blood Pressure Regulators: 1831 Hypertensive Patients Followed Up for Three Years. http://www.plosone.org/article/ info\%3Adoi\%2F10.1371\%2Fjournal.pone.0084522. Download: September 10, 2014.

Chopra S, Baby C, Jacob JJ. 2011. Neuroendocrine regulation of blood pressure. Indian Journal of Endocrinology and Metabolism 15(Suppl4): S281-S288.

Creedon JMB. 2012. Procedure Pro: Indirect blood pressure measurement. http://www.cliniciansbrief.com/sites/default/files/ProP\%20Blood\%20 Pressure\%20Measurements.pdf. Download: June 16, 2014.

Crandall CG, Wilson TE, Marving J, Vogelsang TW, Kjaer A, Hesse B, Secher NH. 2008. Effects of passive heating on central blood volume and ventricular dimensions in humans. Journal of Physiology 586: 293-301.

Cui J, Durand S, Levine BD, Crandall CG. 2005. Effect of skin cooling on central venous pressure during orthostatic challenge. American Journal of Physiology-Heart and Circulatory Physiology 289: 2429-2433.

Isezuo SA. 2003. Seasonal variation in hospitalisation for hypertension-related morbidities in Sokoto, north-western Nigeria. International Journal of Circumpolar Health 62: 397-409.

Jin J. 2014. New guideline for treatment of high blood pressure in adults. Journal of the American Medical Association 311(5): 538.
Kishimoto A, Tochikubo O, Ohshige K. 2007. Relation between nocturnal arterial oxygen desaturation and morning blood pressure. Clinical and Experimental Hypertension 29(1): 51-60.

Kissack CM, Weindling AM. 2009. Peripheral blood flow and oxygen extraction in the sick, newborn very low birth weight infant shortly after birth. Pediatric Research 65: 462-467.

Kyriacou PA, Shafqat K, Pal SK. 2007. Arterial blood oxygen saturation during blood pressure cuff-induced hypoperfusion. Third International Conference on Optical and Laser Diagnostics IOP Publishing. Journal of Physics: Conference Series 85

Levy BI, Schiffrin EL, Mourad JJ, Agostini D, Vicaut E, Michel E, Safar ME, Struijker-Boudier HAJ. 2008. Impaired Tissue Perfusion: A Pathology Common to Hypertension, Obesity and Diabetes Mellitus. Circulation 118: 968-976.

McLellan SA, Walsh TS. 2004. Oxygen delivery and haemoglobin. Continuing Education in Anaesthesia, Critical Care Pain 4(4): 123-126.

Kario K, Modesti PA, Morabito M, Bertolozzi L, Massetti L, Panci G, Lumachi C, Giglio A, Bilo G, Caldara G, Lonati L, Orlandini S, Maracchi G, Mancia G, Gensini GF, Parati G. 2006. Weather related changes in 24-hour blood pressure profile: Effects of age and implications for hypertension management. Hypertension 47: 155-161.

Murakami S, Otsuka K, Kono T, Soyama A, Umeda T. 2011. Impact of outdoor temperature on prewaking morning surge and nocturnal decline in blood pressure in a Japanese population Hypertension Research 34: 70-73.

Schutz SL. 2001. Oxygen saturation monitoring by pulse oximetry. AACN Procedure manual for Critical Care, $4^{\text {th }}$ ed. http://www.aacn.org/WD/Practice/Docs/ch_14_PO.pdf. Download: September 10, 2014.

Tawaf R, Heriyadie D, Anang A, Sulaeman M, Hidayat R. 2011. Empowerment of small holder farmers business Garut sheep in west java. International conference on sustainable agriculture and food security: challenges and oportunity. 27-28 Sept 2011. Universitas Padjajaran. Bandung.

Wilson TE, Crandall CG. 2011. Effect of thermal stress on cardiac function Exercise and Sport Sciences Reviews 39(1): 12-17.

Worthley LIG. 2000. Shock: a review of pathophysiology and management. Part I. Critic Care and Resuscitation 2: 55-65. 